\title{
PENERANGAN JALAN UMUM \\ ANTARA HAK DAN KEWAJIBAN
}

Oleh

Indrati Rini*

\section{ABSTRAK}

Pajak penerangan jalan haruslah berdasarkan UU, hal ini dapat dipahami karena pajak merupakan beban kewajiban rakyat, sehingga benar-benar dari dan untuk kesejahteraan rakyat termasuk pelanggan/ konsumen listrik. Pelanggan/ konsumen listrik wajib membayar pajak penerangan jalan setiap bulannya bersamaan dengan pelaksanaan pembayaran rekening listrik PLN dengan besar nilai pajak ditentukan paling tinggi sebesar $10 \%$ berdasarkan UU No. 34 Tahun 200 dan PP No. 65 Tahun 2001.

Kata kunci : Pajak Penerangan Jalan, Undang-Undang, Hak, Kewajiban

\section{PENDAHULUAN}

Terdengar suara nyaring dari sebagian pelanggan listrik, bahwa masalah penerangan jalan umum merupakan kewajiban dan tanggung jawab dari Pemda, bukan kewajiban dan tanggung jawab rakyat. Oleh karena itu, apabila kewajiban Pemda tersebut tidak dilaksanakan, maka rakyat berhak menuntutnya.

Pelanggan listrik telah membayar Pajak Penerangan Jalan melalui rekening listrik PLN setiap bulan, berarti telah melaksanakan kewajibannya. Oleh karena itu, pelanggan listrik berhak untuk menikmati penerangan jalan, mulai dari jalan-jalan protokol sampai kampung-kampung/gang-gang. Ironisnya, jika "cap kewajiban Pemda-PLN atas Penerangan Jalan Umum (PJU) tidak terpenuhi", maka seolah-olah merupakan hak bagi rakyat untuk melaksanakan PJU sendiri. Diantaranya, masyarakat secara beramai--ramai melakukan pencurian listrik dengan dalih untuk PJU. Dapatkah perbuatan pencurian listrik oleh masyarakat untuk PJU tersebut dibenarkan?

\footnotetext{
- Guru Besar Ilmu Hukum Universitas Wijaya Kusuma Surabaya
} 
Sekarang, tiada salahnya kita mencermati berbagai fakta atau fenomena seputar PJU di sejumlah lokasi. Tentu saja fakta ini sebagai bahan penanggulangan \& pencarian solusi secara kritis faktual, demi kelancaran pasokan listrik di masa mendatang, sehingga kesejahteraan rakyat melalui pelayanan listrik tercapai.

Komisi D DPRD Gresik beberapa saat yang lalu agak jengkel dengan DPU Sub Dinas Kebersihan \& Pertamanan Pemkab, sebab 106 buah lampu penerangan di pusat kota telah lama padam, namun belum diperbaiki. Akibatnya, bila malam hari tiba, kota nampak gelap. Padahal PPJ dari sejumlah pajak daerah lainnya, meraup pendapatan terbesar, yaitu Rp. 15 miliar tahun 2001 \& direncanakan Rp. 17 miliar tahun 2002.

Masih segar dalam ingatan Idta, yaitu kejadian gelap-gulitanya daerah Wonokromo Tangkis, Karangrejo Sawah dan sekitarnya, selama 4 jam, 11 Mei 2002.Warga panik, sementara unit gangguan PLN teleponnya tut-tut àtau hanya terdengar musik penunggu sewaktu dihubungi warga. Lagi-lagi PLN dituding tak becus memelihara jaringan listrik secara memadai. Bahkan anggota DPR Komisi D menganjurkan agar warga mengajukan gugatan class action ke PLN. Setelah dilakukan pengecekan di lokasi oleh para petugas PLN, penyebabnya adalah trafo yang rusak akibat banyaknva PJU liar, di samping gangguan alam, bukan kesalahan treatnew PLN.

Sekarang ada baiknya, kita melihat telah dipasangnya PJU di sejumlah lokasi (faktanya banyak yang hilang), diantaranya di jalan Margomulyo yang kini terang benderang. Puluhan lampu PJU menerangi jalan tersebut yang menghubungkan Tandes dengan Greges. Warga masyarakat, terutama sopir \& penumpang MPU, serta buruh wanita tak perlu lagi takut melewatinya bila pulang malam.

\section{B. PERMASALAHAN}

Dalam hal ini. Tidaklah berlebihan apabila kita mencermati fakta tersebut secara bijak dan arif, artinya menempatkannya secara proporsional dan berimbang, tanpa luapan emosi yang irrasional dalam menyoroti posisi dan perilaku Pemda - PLN di satu sisi, dan 
pelanggan listrik di sisi yang lain, sesuai dengan kemampuan dan kondisi nyata, baik dari sudut hak \& kewajibannya masing-tuasing. Sekarang yang perlu dicari adalah "Solusi terbaik apa, yang dapat digunakan agar PJU dapat direalisir dengan baik, tanpa menimbulkan kerugian, baik bagi masyarakat / pelanggan maupun Pemda-PLN."

\section{PEMBAHASAN}

\section{a. Keberadaan Pajak Penerangan Jalan}

Salah satu sumber pendapatan negara kesatuan RI yang utama adalah pajak. MPR telah menggariskan arah kebijakan ekonomi, khususnya yang menyangkut pajak, yaitu "mengembangkan kebijakan fiskal dengan memperhatikan prinsip transparansi, disiplin, keadilan, efisiensi \& efektifitas, untuk menambah penerimaan negara dan mengurangi ketergantungan dana dari luar negeri". ${ }^{1}$

"Political will" tersebut, tentu saja bersumber pada Hukum Dasar Tertulis, yaitu UUD1945, bahwa "segala pajak

\footnotetext{
' Ketetapan MPR RI No. IV/ MPR/1999 tentang
} GBHN, Sub Bidang Ekonomi untuk keperluan Negara berdasarkan undang-undang." ${ }^{2}$

Dari dua kaidah hukum tersebut, jelas nampak bahwa pajak, termasuk PPJ, haruslah berdasar UU sebagai sumber legitimasinya. Hat ini dapat dipahami, karena pajak merupakan beban kewajiban rakyat, sehingga harus dilaksanakan benar-benar, dari dan untuk kesejahteraan rakyat, termasuk pelanggan/ konsumen listrik.

Dalam tataran otonomi daerah, kemampuan keuangan daerah sebagai pilar utamanya. Tantangan persaingan, baik lokal, nasional maupun global mendorong diberikannya kewenangan pada daerah untuk mengatur, membagi \& memanfaatkan sumber dayanya dengan tetap memperhatikan Asas Perimbangan Keuangan Pusat-Daerah.

Untuk memperjelas makna pajak, termasuk pajak daerah dan PPJ, berikut ini batasannya. "Tax is compulsory contribution from the person to the defray expenses incurred in the common interest

\footnotetext{
UUD 1945, Pasal 23 (2) sebagaimana Setelah Amandemen Kedua.
} 
of all without reference to special benefit conferred." ${ }^{\prime 3}$

Kita ketahui bersama, bahwa penyelenggaraan tugas Pemda dan DPRD, diantaranya dibiayai dari dan atas beban Anggaran Pendapatan dan Belanja Daerah. Sumber pendapatan daerah terdiri atas pendapatan asli daerah berupa hasil pajak daerah, retribusi daerah, hasil perusahaan milik daerah dan hasil pengelolaan kekayaan daerah yang dipisahkan dan lain-lain pendapatan asli daerah yang sah, dana perimbangan, pinjaman daerah dan lain-lain pendapatan daerah yang sah. Dengan demikian jelaslah, bahwa "pajak daerah tergolong ke dalam pendapatan asli daerah". ${ }^{4}$

Pendapatan asli daerah adalah penerimaan yang diperoleh dari sumber-sumber dalam wilayahnya sendiri, yang dipungut berdasar Perda sesuai dengan peraturan perundang-undangan yang berlaku, diantaranya berupa pajak daerah. Pajak Daerah adalah "iuran wajib

${ }^{3}$ Edwin R.A. Seligman, Essays in Taxation, New York, 1925

4 Ada persamaan substansi antara UU No. 22/1999 Tentang Pemda, Pasal 78, dengan UU No. 25/ 1999 Tentang Perimbangan Keuangan Antara Pemerintah Pusat dan Daerah pasal 3 \& 4. yang dilakukan oleh orang pribadi atau badan kepada Daerah tanpa imbalan langsung yang seimbang, yang dapat dipaksakan berdasar peraturan perundang-undangan yang berlaku, yang digunakan untuk membiayai penyelenggaraan pemerintah daerah dan pembangunan daerah". ${ }^{5}$

Selanjutnya jenis pajak, meliputi pajak Propinsi antara lain: pajak kendaraan bermotor dan kendaraan di atas air dan pajak kota/ kabupaten diantaranya : Pajak Penerangan Jalan, Pajak Parkir dan sebagainya. Hasil penerimaan pajak kota/ kabupaten termasuk PPJ, diperuntukkan paling sedikit $10 \%$ bagi desa di wilayah daerah kabupaten yang bersangkutan.

Selanjutnya Peraturan Pemerintah No. 651 tahun 2001 tentang Pajak Daerah menetapkan bahwa "obyek PPJ adalah penggunaan tenaga listrik di - wilayah daerah yang tersedia penerangan jalan, yang rekeningnya dibayar oleh pemerintah

5 Perbedaan utama pajak \& retribusi, adalah prestasi dari pemerintah, demikian UU No. $34 / 2000$ Tentang Perubahan Atas UU No. 18/ 1997 Tentang Pajak dan Retribusi daerah. 
daerah". 6 Subyek PPJ, yaitu orang pribadi atau badan, yang menggunakan tenaga listrik. Adapun wajib PPJ adalah orang pribadi atau badan yang menjadi pelanggan listrik dan atau pengguna tenaga listrik Dalam hal tenaga listrik disediakan oleh PLN, maka pemungutan PPJ dilakukan oleh PLN.

Dasar pengenaan PPJ adalah nilai jual tenaga listrik, yaitu dibedakan antara tenaga listrik yang berasal dari dan bukan dari PLN. Dalam hal tenaga listrik berasal dari PLN, maka nilai jualnya, yaitu jumlah tagihan beaya beban ditambah dengan beaya pemakaian Kwh, yang ditetapkan dalam rekening listrik.

Tarif PPJ versi PP No 65/ 2001 adalah sama dengan UU No 34/ 2000 bahwa paling tinggi sebesar 10\%. Juga PPJ yang dipungut oleh PLN, maka besarnya pokok pajak terutang dihitung berdasar jumlah rekening listrik yang dibayarkan oleh pelanggan PLN, serta dipungut di wilayah daerah tempat penggunaan listrik.

Selanjutnya Menteri Dalam Negeri menetapkan bahwa "pemungutan PPJ

6 Suatu UU baru dapat dilaksanakan, apabila ada Peraturan Pernerintah yang menindaklanjutinya, demikian UU No. 34/ 2000dan PP No. 65/ 2001. hanya pemungutan PPJ atas penggunaan tenaga listrik yang disediakan oleh PLN"? Di sini, PLN sebagai Perseroan Terbatas Perusahaan Listrik Negara, adalah PLN Unit Bisnis Distribusi PLN Wilayah, PLN Cabang dan PLN Unit Pelayanan, termasuk anak perusahaan PLN yang menjual tenaga listrik kepada masyarakat.

Pelanggan listrik wajib membayar PPJ setiap bulannya bersamaan dengan pelaksanaan pembayaran rekening listrik PLN. Kemudian PLN wajib menyetor hasil penerimaan PPJ ke Kas Daerah atau tempat lain yang ditunjuk Pemda."Antara Kepala Daerah dan Pimpinan PLN membuat naskah kerja sama atas pemungutan dan penyetoran PPJ". 8

Khusus bagi kota Surabaya, "PLN adalah Perusahaan Listrik Negara (Petsero) Distribusi Jatim Cabang Surabaya Utara dan Selatan". Materi Perda ini secara

7 Keputusan Mendagri No. 10/2002 Tentang PPJ memper tegas bahwa pasokan tenaga listrik hanya oleh PLN

8 Kerjasama Dinas Pendapatan Daerah - PLN sebagai dasar kelancaran pelaksanaan PPJ, SK. Walikotmadya Daerah TK II Surabaya No. 8/ 1999 Tentang Juklak, Perda No. 16/ 1998.

9 Sebagai penegasan mengenai daerah distribusi listrik, Perda Kotamadya Daerah Tk. II Surabaya No. 16/19968 Tentang Pajak Penerangan Jalan. 
mendasar serupa dengan UU, PP dan Kep.Mendagri menganai PPJ, Kekhususannya, tarif PPJ untuk golongan bukan industri yang pasokan listriknya dari PLN sebesar 9\%, dan untuk golongan industria / usaha sebesar 3\%, sedangkan yang pasokan listriknya bukan dari PLN sebesar $9 \%$.

Yang menarik dari Perda tersebut, bahwa Walikota berdasarkan permohonan wajib pajak, dapat memberikan pengurangan, keringanan dan pembebasan pajak terhadap tenaga listrik, baik berasal dari PLN maupun bukan dari PLN, yang semata-mata untuk melayani kepentingan umum, keagamaan, sosial kesehatan, pendidikan dan kebudayaan.

Pada akhirnya, Walikota Surabaya menginstruksikan agar "Kepala Dinas Pendapatan Daerah Kota Surabaya untuk mengambil langkah-langkah pelaksanaan Pajak Penerangan Jalan". ${ }^{10}$ Langkah-langkah tersebut meliputi penataan administrasi, penyuluhan/ sosialisasi tentang PPJ dan koordinasi dengan instansi terkait sesuai keperluan."

10 Instruksi Walikota Surabaya No. 7/ 1999 Tentang Pelaksanaan PPJ : Perda No. 16/ 1998
Pengaturan PPJ yang terkesan normatif tersebut memang harus diterima, tak dapat dielakkan, namun bukan berarti tidak dapat kita kritisi. Yang agak aneh yaitu praktek pembayaran PPJ oleh pelanggan listrik, yang seharusnya dibayar kepada Pemkot namun kepada PLN. Selanjutnya PLN melaporkannya kepada Pemkot c/q Dinas Pendapatan Daerah. Dalam hal ini "Dispenda hanya dititipi dana PPJ yang tersimpan di Bank Jatim, kemudian Dispenda melalui Bagian Keuangan membayar rekening PPJ ke PLN, aliran dana ini sebagai peninggalan sistem sentralistik pemerintah lama, yang bertujuan mempermudah penagihan rekening listrik, termasuk PPJ". 11

Teknik penagihan listrik semacam ini, nampaknya sinkron dengan dalil yg diajarkan Adam Smith, yaitu "convenience of payment principle: every tax ought to be levied at the time, or the manner, in which it is most likely to be convenient for contributor to pay it". ${ }^{2}$ Dalam hal ini,

1 Hasil Wawancara dengan Kepala Sub Dinas Penagihan dan Keberatan Dispenda Surabaya, 15 Juli 2002

12 Adam Smith, An Inquiry In To The Nature and Canses of The Wealth of Nations, 1970 
waktu yang paling tepat untuk memungut PPJ, yaitu saat membayar rekening setiap bulan di PLN.

Pelanggan listrik tak semuanya memahami alur dana PPJ dan peruntukannya. Tahunya hanya bayar rekening listrik ke PLN, maka apabila lampu penerangan jalan tak terpasang, PLN yang harus bertanggung jawab. Padahal tak semua dana hasil PPJ, kembali utuh untuk penerangan jalan, diantaranya untuk "traffic light", dan sebagainya. Fakta inilah yang harus disosialisasikan pada masyarakat, bahwa PPJ adalah suatu jenis pajak yang tidak ada prestasi langsung dari Pemkot. Hasil PPJ Surabaya 2001 sebesar Rp. 35,131 M, realisasinya Rp.42,91 M.

Di sisi lain, DPRD sebagai mitra kerja Pemkot, sekaligus dapat sebagai sarana kontrol kinerja Pemkot-PLN atas PPJ dan PJLJ, diantaranya banyaknya pengeprasan pohon yang dilakukan PLN.

\section{b. Dampak Pencurian Listrik}

Nampaknya PT. PLN (Persero) tak berdaya menghadapi maraknya pencurian listrik. Uang negara hampir setiap bulan lenyap, sekitar Rp.1,2 M. Komplotan pencuri listrik ini ada yang digunakan untuk Penerangan Jalan Umum. Kerugian akibat meluasnya PJU liar ini, tidak hanya bersifat finansial, namun lebih utamanya yaitu menurunnya layanan PLN terhadap pelanggan. Manajer Umum PT. PLN Unit Bisnis Distribusi Jatim mengungkapkan, bahwa "PLN mendata PJU yang dipasang warga Surabaya di kampung-kampung mencapai 7 juta VA, kalau dihitung dengan tarif listrik PJU Rp. 510 per $1 \mathrm{KWh}$ mencapai Rp. 1,2 M per bulannya". ${ }^{13}$

"Dalam laporan P2TL Area Pelayanan Surabaya Selatan, OPAL SEMERU 2002", ${ }^{14}$ antara lain terdata target pemeriksaan 387 ; realisasi 360 ; jumlah pelanggan melanggar 15 ; besar tagihan susulan pem.daya (VA) 279.100, pem.energi $(\mathrm{kWh}) 316.138$ total sejumlah Rp. 116.141.395, dibayar Rp. 4.057.755, saldo Rp. 112.085.64.

Di Jember ternyata tahun $2000 \mathrm{PJU}$ liar tumbuh subur. Ditengarai akibat pencurian listrik untuk PJU, PLN Jember

13 Pri, "Sebulan PLN Bobol RP. 1,2 M", SURYA, Surabaya, 15 Mei 2002, h. 13.

14 PT. PLN (PERSERO) UB. Distribusi Jatim AP, Surabaya Selatan, Unit. Jaringan, 29 Januari -5 Pebruari 2002, Rekapitulasi Laporan P2TL. Area Pelayanan Surabaya Selatan 
menderita kerugian rutusan juta rupiah per bulan. Di sini, lampu penerangan jalan memang penting, terutama bagi masyarakat perbatasan atau pinggiran, namun apa harus dengan mencuri listrik. Lampu-lampu mercuri yang dipasang warga rata-rata 500 watt yang mencapai puluhan titik di satu kawasan.

Tindak pencurian listrik di Surabaya setahun terakhir malah lebih banyak di sektor industri, mulai dari hotel sampai pabrik kecil. Penyelesaian cenderung di bawah tangan, sehingga uang negara masuk ke oknum-oknum. Hasil Penertiban Pemakaian Tenaga Listrik/ P2TL yang digelar PLN 3 bulan terakhir, dari 3.695 rumah yang diperiksa ada sekitar 384 rumah yang diketahui mencuri listrik, kerugian sekitar Rp. 1.074 M. Sedangkan industri yang melakukan tindakan serupa sebanyak 92 lokasi dengan kerugian Rp. 400 juta.

Modus operandi pencurian listrik biasanya dengan cara klasik yaitu memberi saklar atau alat, agar dapat menghambat putaran listrik. Jika petugas PLN datang, alat-alat tersebut dilepas. Cara lain, yaitu membakar kumparan yang ada di dalam meteran PLN, jika alat pencatat meteran tersebut rusak, maka biaya yang dikeluarkan kecil sehingga kerugian menjadi beban PLN.

"Hasil Operasi Pijar Semeru POLDA JATIM dan jajarannya", 15 diperoleh data antara lain: jumlah tersangka/ kasus 116, barang bukti berupa : handel pengatur arus, timer, konektor, MCB, stop kontak, cemiti, tukur, paku, jarum, dan plastik. Hambatan yang terjadi, yaitu belum ada kesamaan tindakan dari penyidik POLRI terhadap pelaku, mengingat struktur masyarakat yang berbeda-beda. Ada yang penyelesaiannya dilakukan oleh PLN secara perdata , melalui pembayaran denda berdasarkan perhitungan PLN. Sementara ada beberapa kasus yang diteruskan oleh POLRI secara pidana.

Sekarang, saatnya kiita pahami bersama bahwa pencurian listrik, dari segi apapun merupakan perbuatan terlarang dan tidak patut dilakukan oleh orang yang beradab. Pencurian adalah tindak pidana

15 Laporan Analisa dan Evaluasi OPS Kepolisian Kewilayahan "Pijar Semeru 2002 POLDA Jatim dan Jajaran, 24 Januari - 7 Pebruari 2002", Direktorat Reserse POLDA Jatim. 
yang tergolong sebagai kejahatan, sehingga pencuri listrik disebut penjahat. Jika kita termasuk pelakunya, relakah menyandang gelar tersebut?

Batasan pencurian yaitu "barang siapa mengambil barang sesuatu, yang seluruhnya atau sebagian kepunyaan orang lain, dengan maksud untuk memiliki secara melawan hukum, diancam karena pencurian, dengan pidana penjara paling lama lima tahun atau denda paling banyak enam puluh rupiah". ${ }^{16}$ Ketentuan ini dapat ditindaklanjuti dengan ketentuan-ketentuan UU No.15/ 1985 tentang Ketenagalistrikan khususnya pasal 19 dan 20, serta KUHP pasal 263, 55 dan 56. Pendek kata, unsur pencurian berupa unsur obyektif, yaitu barang yang seharusnya milik orang lain, dan unsur subyektif, yaitu tanda-tanda untuk memiliki sesuatu barang.

Selanjutnya, yang perlu dianalisis lebih mendalam, adalah listrik tergolong produk barang atau jasa?

Barang (goed, zaak) berdasar wet-historische interpretatie, yang dimaksud "barang/ benda waktu itu adālah

16 Moeljatno, Kitab Undang-Undang Hukum Pidana, Bina Aksara, Jakarta, 1985, Pasal 362. benda berwujud". ${ }^{17}$ Kemudian arti barang tersebut oleh Hoge Raad, Belanda, tanggal 23 Mei 1921, dalam arrestnya ditetapkan, bahwa "barang tidak hanya ditafsirkan sebagai benda berwujud saja (staffelijk goed), tetapi juga sebagai benda tidak berwujud, termasuk listrik. Pada waktu KUHP dibuat, belum dikenal listrik, sekarang sangat dibutuhkan masyarakat. Dewasa ini Pemkot-PLN Surabaya sedang menyiapkan alat canggih yang dapat mendeteksi perilaku pelanggan, berfungsi secara otomatis memberi sinyal, apabila ada rumah/ industri yang dicurigai. Bagi PJU, Pemkot - PLN akan memasang meteran listrik, seperti yang dipraktekkan di Jombang, di mana PJU illegal dapat ditekan yaitu satu kawasan ada 5 atau 10 titik yang memakai 1 meteran.

Sampai saat ini, jarang terdengar pencurian listrik, yang dilakukan industri atau rumah tangga, maupun untuk PJU diproses sampai pengadilan. Penanggulangan secara bersama-sama dan terpadu baik dari operasi petugas gabungan Penyidik PNS-PLN dan POLRI maupun

17 Satochid Kartanegara, dkk., Hukum Pidana, Balai Lektur Mahasiswa, Jakarta, t.th. 
laporan dari masyarakat, kita optimis pencurian listrik, khususnya untuk PJU, dapat ditekan bahkan dikikis habis. Asumsinya "apabila pencurian listrik dapat ditanggulangi, kenaikan tarif dasar listrik tak akan terjadi".

Di sisi lain, masyarakat pencuri listrik untuk PJU merasa malu dan menghentikan perbuatannya, bukan malah nekat mengancam mengacungi parang pada petugas yang benar-benar melaksanakan penertiban. Sebaliknya, petugas yang berakhlaq mulia, tidak tergiur melakukan $\mathrm{KKN}$, bahkan memeras pelanggan yang mencuri listrik. Masyarakat yang ingin memasang PJU demi kepentingan orang banyak, haruslah melalui prosedur yang benar, diantaranya memohon atau melapor ke PLN, jika diterima kemungkinan biaya penggunaan te.naga listrik akan ditanggung oleh Pemda - Pemkot.

\section{c. Posisi Pelanggan Listrik}

Ada informasi mutakhir, bahwa saat ini PLN memang sudah tidak mendistribusikan daya listritk sebēsar 450 VA untuk pelanggan baru. Calon pelanggan baru harus mau pasang daya sebesar minimum $900 \mathrm{VA}$ atau $1300 \mathrm{VA}$, dengan syarat-syarat yang cukup ketat. Benarkah kebijakan ini diterapkan di masyarakat?

Alkisah, terjadi dialog antara sopir taksi asal Cilacap dengan YLKI-PLN : "saya hanya butuh $450 \mathrm{VA}$, tetapi dipaksa oleh PLN untuk memasang 1300VA, saya tidak mampu membayar, saya minta PLN membatakan kebijakan yang tidak bijak itu". ${ }^{18}$

Kebijakan tersebut hendakaya disoroti tidak sacara formal-yuridis tetapi juga sosial-ekonomi. Secara internasional, Indonesia saat ini dapat digolongkan sebagai negara miskin, bukan "developing country" (negara sedang berkembang), sebab pendapatan per kapita US\$ 680 . Padahal indikator standar pendapatan per kapita negara berkembang adalah 800 US\$. Hal ini berarti pendapatan rata-rata penduduk Indonesia sekitar Rp. 400 per bulan.

Saat ini penduduk Indonesia yang diterangi listrik sejumlah $56 \%$, yaitu $80 \%$ desa di Jawa dan $20 \%$ di luar Jawa. Setelah

18 "Masa Depan Konsumen Listrik", Warta Konsumen, Juni 2002. 
berlakunya TDL yang melalui 4 tahapan, yaitu : (1) Jan-31 Maret 2002; (2) 1 April -30 Juni. 2002; (3) 1 Juli - 30 Sept; (4) 1 Ok-t - 31 Des 2002, dengan tarif berkisar Rp. 455 per KWH. Harga jual ini merupakan basil negosiasi antara Pemerintah, PLN dan perwakilan terkait, di antaranya Yayasan/ Lembaga Konsumen Swadaya Masyarakat.

Pelanggan listrik (customers), bukanlah sekedar konsumen listrik. Mereka acapkali tak berdaya menghadapi perilaku PLN yang terkesan sepihak. Di antaranya ketentuan yang tersurat di rekening : "PT. PLN (Persero) berhak melaksanakan pemutusan sementara penyaluran tenaga listrik pada pelanggan, apabila pelanggan belum melunasi pembayaran rekening listrik dalam waktu yang ditentukan oleh PT. PLN (persero)".

Klausul $a$ baku (standard contract) yang dibuat PLN, seolah-olah tak mampu dibendung pelanggan. Ada benarnya Donald Black yang menyatakan bahwa ; "downward law is greater than upward law, and law varies directly with stratification". ${ }^{19} \quad$ Peraturan hukum mengalir lebih deras ke bawah, dan berlakunya peraturan berbeda menurut lapisan masyarakatnya. Tiada kata yang dapat diucapkan, selain "Take it or leave $i t^{\prime \prime}$, jika mau berlangganan patuhi syarat-syaratnya, jika tidak, tinggalkan saja.

Pertanyaan yang dapat muncul dari kondisi tersebut, antara lain: "sudahkah keluhan pelanggan yang menyangkut baca meter, laporan gangguan, penyumbungan baru, pembayaran tagihan, informasi listrik fasilitas diskon, dan lain-lain benar-benar telah dilaksanakan sepenuh hati" ? Hal-hal tersebut perlu ditanggapi secara fair dan transparan. Hal ini disebabkan adanya hak-hak konsumen, diantaranya, yaitu 11 hak untuk diperlakukan atau dilayani secara benar, jujur, serta tidak diskriminatif", dan hak untuk mendapatkan kompensasi ganti rugi dant atau penggantian kerugian, apabila barang dan atau jasa yang diterima tidak sesuai dengan

19 Donald Black, The Behavior of Law, Yale University, Academic Press, Now York, 1976. 
perjanjian atau tidak sebagaimana mestinya". 20

Selanjutnya, pelanggan listrik diharapkan, tidak saja getol memperjuangkan hak-haknya, tapi juga melaksanakan kewajibannya, diantaranya, membayar rekening listrik dan memelihara meteran listrik. Di samping itu, pelanggan tidak lagi menjadi penggantol listrik liar termasuk untuk PJU, sehingga mereka terlepas dari kewajiban membayar pajak PJU.

Dirjen Pajak Depkeu menyatakan, bahwa "kesadaran wajib pajak Indonesia masih memprihatinkan, orang Indonesia masih lebih taat membayar rekening listrik dan PDAM, daripada membayar pajak". 21 Seperti kita ketahui bersama, bahwa "Tax ratio" Indonesia adalah $13 \%$, masih rendah dibandingkan Malaysia dan Singapura. Di Jerman bisa mencapai 30 \%, karena hampir semua barang menjadi obyek pajak. Padahal potensi pajak termasuk pajak PJU, dalam menyokong

20 Ada sejumlah hak konsmen, termasuk pelanggan listrik, demikian UU No. 8/ 1999 Tentang Perlindungan Konsumen (sebagai umbrella act.).

21 Kim, "Lebih Taat Bayar Rekening Listrik-PDAM", Jawa Pos, 7 Juni 2002
Pendapatan Domestik Bruto cukup besar. Adapun posisi penerimaan pajak, termasuk pajak PJU dapat dilihat dalam tabel berikut ini.

\section{Posisi Penerimaan Pajak} Per 31 Mei 2002

\begin{tabular}{|l|l|l|}
\hline \multicolumn{1}{|c|}{$\begin{array}{c}\text { Jenis } \\
\text { Pajak }\end{array}$} & \multicolumn{1}{|c|}{ Pencapaian } & \multicolumn{1}{c|}{ Target 2002} \\
\hline & & \\
PPh & Rp. 39,2 triliun & Rp. 104, 49 triliun \\
PPN & Rp. 22,7 triliun & Rp. 70, 1 trillun \\
PBB & Rp. 2,11 triliun & Rp. 8, 13 triliun \\
Pajak Lain & Rp.524,3 millar & Rp. 1, 95 triliun \\
\hline Total & Rp. 68,3 triliun & Rp. 184,76 triliun \\
\hline
\end{tabular}

Sumber: Ditjen Pajak, 2002.

Masyarakat pelanggan listrik diharapkan dapat menjadi sarana kontrol sosial bagi PLN dan mitra kerjanya. Di samping itu, PLN masih dibutuhkan pasokan listriknya bagi masyarakat. Misalnya, PT. Maspion termasuk perusahaan yang sangat bergantung pada listrik untuk menjalankan produksi, yaitu hampir $70 \%$, baru sisanya dari BBM dan gas bumi.

PT. Kertas Leces justru sebaliknya, ketika pasokan gas lagi tipis, justru bersiap-siap mengganti BBM dengan gas, mulai bulan September 2002. Kebutuhan rata-rata BBM setiap harinya mencapai 500 kilo liter atau 12 juta ton BBM/ bulan. Pemakaian gas lebih ekonomis, diantaranya 
pembayaran gas dapat dilakukan ancaman atau pemogokan massal. belakangan sedungkan BBM harus dibayar Benarkah di balik swastanisasi di muka.

ketenagalistrikan nasional, akan

Kita berharap PLN tidak terus merugi, bahkan bangkrut, sehingga pasokan listrik tidak sampai beralih ke negara lain, serta mampu mandiri, bersaing secara sehat, profesional, transparan dan bebas dari KKN. Hal ini akan menjadi kebanggaan dan kepuasan bagi pelanggannya atas pasokan dan layanan energi listrik di masa mendatang.

\section{d. Prospek PT. PLN (Persero)}

Upaya Pemerintah dalam mengatasi krisis ketenagalistrikan nasional, berupa kegiatan-kegiatan restrukturisasi industri, pengenalan kompetisi penetapan tarif, pengembalian biaya dan subsidi rasionalisasi dan ekspansi partisipasi swasta, redefinisi peran pemerintah, serta memperhatikan kerangka pengaturan hukum.

Pelaksaanan program swastanisasi ketenagalistrikan nasional, sontak disambut gembira oleh sebagian pihak, dan sebagian menimbulkan kesengsaraan rakyat banyak? Ketenagalistrikan nasional sekarang merupakan sektor yang dibutuhkan masyarakat luas, yang mana telah diatur, bahwa "cabang-cabang yang penting bagi negara dan menguasai hajat hidup orang banyak dikuasai oleh Negara". Kompetisi pasar atas pengadaan listrik di Jawa dan Bali dimulai sejak tahun 1999 dengan "pembeli tunggal" atau single buyer, dan pada tahun 2003 dengan multiple seller and buyer. Jika hal ini terjadi, maka "tidak ada monopoli distribusi listrik". 22

Harga listrik di Indonesia sekarang ini termasuk yang termurah di dunia, yaitu 3,03 cent US\$/ kWh dengan GNP/ kapita 680 US\$. India 6,6 cent dengan GNP/ kapita 324 US\$, sedangkan Belgia paling mahal, yaitu 18,8 cent US\$/ kWh dengan GNP/ kapita 19.200 US\$. Saat ini tarif listrik rata-rata lebih rendah, dari harga pokok penjualan, yaitu sekitar Rp. 455 per kWh.

lagi melakukan penolakan, bahkan sebagian karyawan PLN melakukan

22 Faktor-faktor Monopoli \& Persaingan UsahaTidak Sehat, dilarang UU No.5/ 1999 
Sistem ketenagalistrikan nasional meliputi: pembangkit, transmisi, dan distribusi baru sampai pada konsumen. Biaya terbesar adalah pembangkitan 81, $4 \%$, transmisi $10,5 \%$ di mana hampir semua peralatannya dan pembeliannya berasal dari pinjaman luar negeri, diantaranya Asian Development Bank, dan distribusi sekitar $7-8 \%$ dan alokasi pegawai $1-20 / 6$.

Keputusan Pemerintah untuk me-write up utang senilai Rp. 20,8 triliun, sangat membantu kinerja keuangan PLN. Hal ini disebabkan tahun 2001 terjual kenaikan rata-rata TDL sebesar 17, $47 \%$ dan PLN juga berhasil bernegosiasi dengan mengurangi harga listrik swasta. Kenaikan TDL rata-rata $6 \%$ mulai Januari 2002 telah disetujui oleh Pemerintah dan DPR. Kenaikan ini dikarenakan pengurangan subsidi dari Rp. 4,5 triliun menjadi Rp. 4,1 triliun dalam RAPBN 2002.

Guna mendanai 44 proyek pembangkit listrik dan transmisi baru di luar Jawa dan Bali sampai tahun 2005, dibutuhkan investasi sekitar Rp. 99 triliun. Dewasa ini di luar Jawa dan Bali terdapat 24 daerah krisis listrik, antara lain :
Kupang (NTT), NTB dan Sumsel. Di Jatim dicanangkan program pembangunan pembangkit listrik Paiton III-VI. Oleh karena itu, perubahan TDL diharapkan mendongkrak pendapatan PLN, sekaligus menekan kerugiannya. Kalau kondisi ini bertahan terus sampai 3 tahun, bisa jadi PLN dapat impas (break event point), bahkan dapat meraih laba di waktu mendatang.

Saat ini PLN sedang berupaya keras menekan losses $\mathrm{kWh}$, termasuk pencurian PJU. Losses teknis di negara maju, besarnya sekitar $5 \%$, sedangkan di PLN $8-9 \%$, yang ditolerir sampai $7 \%$. Untuk losses non-teknis sekitar $24 \%$. Losses tersebut bisa untuk keperluan PJU, rumah tangga, industri-usaha, bisa jadi oleh oknum PLN. Oleh karena itu, kesinambungan Operasi Tim P2TL (Penertiban Pemakai Tenaga Listrik) dengan dukungan seluruh komponen masyarakat sangaja dibutuhkan.

Himbauan PLN Unit Bisnis Distribusi Jatim agar para pelanggan hemat listrik terlihat diantaranya melalui iklan atau sticker, yaitu : " Hemat Listrik Sama Dengan Hidup HematDalam rangka 
mengantisipasi, bahkan memperlambat datangnya krisis listrik lebih cepat dari prediksi tahun 2004, maka hendaknya pelanggan ikut menyemarakkannya, diantaranya hemat listrik pada saat beban puncak, sebagaimana dalam tabel berikut ini.

\section{Beban Puncak Listrik Sistem Jawa-Bali Di Jatim (Mega Watt/MW)}

\begin{tabular}{|l|l|l|}
\hline \multicolumn{1}{|c|}{ Tahun } & \multicolumn{1}{|c|}{ Siang } & \multicolumn{1}{c|}{ Malam } \\
\hline 1999 & 1.803 & 2.531 \\
2DW & 1.881 & 2.658 \\
2001 & 1.843 & 2.789 \\
2W2 & 1.895 & 2.850 \\
\hline
\end{tabular}

Sumber : PLN UBD Jawa Timur, 2002.

Berdasarkan tabel di atas, beban puncak terlihat pada malam hari yaitu, antara pukul 18.00 sampai 21.00 WIB. Perusahaan-perusahaan di Jatim, apabila ada yang mempunyai unit pembangkitan, PLN bersedia membeli kelebihan energi listrik yang dihasilkannya. Hal ini sebagai pilihan terbaik, daripada menunggu peningkatan pasokan listrik dari unit pembangkitan, diantaranya Indonesian Power.

Dalam upaya meningkatkan pelayanan kepada masyarakat, PLN telah meluncurkan berbagai program, antara lain :"Pasang Baru Listrik Berasuransi
Menggandeng Bank atau Wartel Sebagai Mitra Kerja Pembayaran Listrik, Laris 900 PLN, Call Centre 123 PLN, Efficiency Drive Program, Percepatan Pembayaran Rekening, Layanan Gangguan 24 Jam", dan program lainnya.

Sebagai landasan hukum sektor ketenagalistrikan nasional, diantaranya adalah UU No. 15/ 1985, yang apabila dibandingkan dengan Rancangan Undang-Undang ketenagalistrikan : kalau dulu pengelolaan bisnis listrik masih tercampur dengan listrik sebagai misi sosial. Juga harga jual, tarif dan subsidi ditetapkan oleh pemerintah. Di samping itu kebijakan lama berupa struktur vertically integrated menyangkut pembangkit, transmisi dan distribusi, serta pengaturan hukum oleh pemerintah (Dirjen Energi dan Sumber Daya dan Mineral), perizinan oleh pemerintah dan partisipasi swasta tidak jelas.

\section{Sekarang diberlakukan unbundled} structure terpecah untuk Jawa dan Bali, sedangkan vertically integrated structure untuk luar Jawa dan Bali. Juga diberlakukan sistem bursa, sistem operator, 
multi buyer and multi seller system, serta perizinan diberikan oleh pusat dan daerah.

Selanjutnya pengaturan oleh Badan Pengatur, yaitu badan hukum milik negara yang memiliki kewenangan dan tanggung jawab, serta pengambilan keputusan secara independen untuk melaksanakan pengaturan dan pengawasan penyediaan tenaga listrik, partisipasi swasta transparan, serta adanya larangan praktek monopoli swasta, juga adanya perlindungan kepentingan masyarakat umum termasuk konsumen listrik, serta forum public hearing antara pemerintah, pelaku usaha dan konsumen yang dihadiri oleh Badan Perlindungan Konsumen Nasional.

Pada akhirnya, prospek PT. PLN (PERSERO) masih tergantung pada bukti di lapangan dan kemampuannya dalam berkoordinasi dengan Badan Pengatur, Pemerintah/ Pemda, DPRD dan instansi yang terkait, serta dukungan dari segenap lapisan masyarakat, baik perorangan maupun kolektif, dari tingkat RT/ RW, Kelurahan/ Kecamatan serta pelaku bisnis juga LSM termasuk Lembaga Perlindungan Konsumen Surabaya, Yayasan Konsumen Surabaya Jawa Timur, Yayasan Lembaga
Perlindungan Konsumen Jatim, kita menunggu keberhasilan PLN dalam persaingan nasional, regional dan global.

\section{PENUTUP}

Berikut ini disampaikan beberapa solusi penyelesaian :

1. Tindak tegas pencuri listrik, khususnya untuk PJU melalui jalur hokum pengadilan.

2. Tindak tegas petugas PLN atau mitra kerja PLN/ Pemborong Pencatat Meter yang ber-KKN dengan pelanggan yang diduga mencuri listrik.

3. Pemasangan dan pemeliharaan PJU perlu koordinasi dan pelaporan setiap periode oleh Pemkot/ Dinas Pertamanan - PLN - Pelanggan.

4. Memisahkan atau memberikan bukti pembayaran terpisah untuk rekening listrik dan pajak PJU.

5. Memberikan insentif atau bonus bagi petugas PLN/ mitra kerjanya dan masyarakat umum yang melaporkan atau memberi informasi adanya dugaan pencurian listrik, khususnya untuk PJU. 
6. Segera dibentuk Forum Pelanggan Listrik yang anggotanya mewakili setiap unsur pelanggan.

7. Public Hearing antara Pemda/ Pemkot DPR - PLN dan instansi terkait dilestarikan, bahkan sedapatnya melibatkan pelanggan/ konsumen listrik.

8. Bagi masyarakat yang secara legal-procedural memohon PJU, diberikan kepastian, diterima atau ditolak, bahkan jika perlu dibuat kontrak antara Pemda/ Pemkot - PLN dengan pelanggan di masing-masing daerah, baik RT/ RW atau Kelurahan/ Kecamatan tentang kesanggupan pemasangan dan pemeliharaan PJU.

9. Secara periodik disediakan dana untuk penyuluhan/ sosialisasi tentang pajak PJU termasuk peruntukannya dan membuat pelaporan beserta eavaluasi keberhasilan dan kegagalannya.

\section{DAFTAR PUSTAKA :}

Edwin R.A. Seligman, Essay in Taxation, New York, 1925.

Direktorat Ditserse Polda Jatim, Pijar Semeru 2002.
Donald Black, The Behavior of Law, Yale University, Academic Press New York, 1976.

Indrati Rini, Tantangan Swastanisasi Ketenagalistrikan Nasional, SURYA, 13 Mei 2002.

Kim, Lebih Taat Bayar Rekening Listrik-PDAM, Jawa Pos, 7 Juni 2002.

Moeljatno, Kitab Undang-Undang Hukum Pidana, Bina Aksara, Jakarta, 1985.

Pri, Sebulan Bobol PLN Rp. 1,2 M, Surya, 15 Mei 2003.

R. Santoso Brotodihardjo, Pengantar Ihnu Hukum Pajak, Eresco, Jakarta, 1979.

Satochid Kartanegara, Hukum Pidana, Balai Lektur Mahasiswa, Jakarta, t.th.

YLKI, Masa Depan Konsumen Listrik, Warta Konsumen, Jakarta, 2002.

Undang-Undang Dasar 1945 Amandemen Kedua.

Ketetapan MRR RI. No. IV MPR RI 1999, Tentang GBHN.

Undang-Undang No. 15 Tahun 1985 Tentang KetenagaListrikan.

Undang-Undang No. 8 Tahun 1999 Tentang Perlindungan Konsumen.

Undang-Undang No. 34 Tahun 2000 Tentang Pajak dan Retrebusi Daerah. 